\title{
Determinants of The Participation of Economic Actors in The Agro-Pastoral Fair in North-East Benin: Case of The Departments of Borgou and Alibori
}

\author{
Fabrice Dossa $\mathrm{K}^{*}$ and Christian Todota T \\ Department of Economics and Rural Sociology, University of Parakou, Benin
}

Submission: April 10, 2018, Published: August 02, 2018

"Corresponding author: Fabrice Dossa K, Department of Economics and Rural Sociology, Faculty of Agronomy, University of Parakou, BP 123, Parakou, Benin; Email: fabdossa@gmail.com

\begin{abstract}
In a context where agriculture plays a vital role in the life of Benin's population, it is important to pay particular attention to the various evils that undermine its evolution. Among these many evils are the difficulties related to market access for agricultural products. One of the strategies implemented in North-East Benin, precisely in the Borgou-Alibori zone to improve market access for agricultural products, is the organization of agropastoral fairs. The objective of this study is to analyze the determinants of the participation of economic actors in the Agro-Pastoral Fair (FAP) in North-East of Benin, taking for reference the 4th edition held from 16 to 21 November 2017 in the commune of Kalalé. After a count of participants, a sample of 50 people was surveyed. The information collected concerned the characteristics, motivations and satisfaction of fairground visitors. Most of the participants in the fair are affiliated with an OSP and are women involved in the agriculture and agri-food sector. The few men represent the sectors of agricultural crafts and livestock. The study also revealed that the main motivations of the participants in the fair are intrinsic (gaining experience, improving production and marketing techniques) and extrinsic (increasing income, acquiring potential customers, making themselves known and know their groupings) with a predominance of intrinsic ones. In addition, carnivals in the livestock sector are less motivated than those in other sectors. This is because of the dietary and hygienic requirements of animals that increase the costs of participation compared to other sectors of activity. In terms of satisfaction, the feedback from the showmen is good overall but they face constraints that prevent unanimous satisfaction (period of the fair and organizational aspects).
\end{abstract}

Keywords: Determinants; Participation; Fair; Motivation; Satisfaction

\section{Introduction}

Agriculture is an income generating activity for producers and a productive sector for the national economy [1]. Like many West African countries, it represents the first economic activity in Benin. It contributes $4 \%$ to economic growth and, on average, $23.5 \%$ to GDP [2]. However, this sector still faces enormous difficulties that limit its performance. Apart from the problems directly related to production, farmers as breeders very often put marketing as a major problem [3]. They face real difficulties in selling their products on the markets and complain about the low value they derive from them. Many people deplore "prices that are too low", "irregular prices", power struggles against them in "unstructured markets" and "unorganized sectors" [4]. These difficulties negate the success achieved at the production level [5]. One of the key links for a healthy and productive agricultural sector is the marketing of agricultural products. Without an effective marketing process, the agricultural sector cannot contribute significantly to national development. Contributing to improving market access for agricultural products is an essential step towards reducing poverty and food security [6]. Conscious of this, socio-professional organizations have developed multiple initiatives to improve the market relation of their member producers [7]. Among these initiatives is the idea of organizing agricultural or agro-pastoral fairs which, like other mechanisms such as warrantage and SIM (Market Information System), provide facilitation tools. development of the agricultural sector. According to [8], these fairs are an essential meeting point for professionals in the green sector, trade and scientific research in agro / biotechnology. It is a strategy used by development actors to create the conditions for a prosperous agriculture. Among the agricultural organized in Benin, there is the agricultural and financial fair called "AgriFinance", the National Fair of Agricultural Technologies (Fonateca), the Agricultural Fair of Mono Couffo, all organized in South Benin. The agropastoral fair organized in the north in the departments of Borgou and Alibori aims to support Socio-Professional Organizations (OSP) in improving the productivity and marketing of their agricultural, pastoral and agri-food products [9]. It is of 
great importance in market access for agricultural products. Evidenced by the fairly consistent participation of economic actors in the event. The first three editions respectively saw a mobilization of 71, 52 and 80 exhibitors for an average of 67 exhibitors [10]. This situation raises many questions. We seek to know the motives of participation of these different actors in the fair agropastoral and their degree of satisfaction at this fair. This study was conducted to try to answer these questions. It aims to analyze the determinants of the participation of economic actors in the agro-pastoral fair North-East of Benin.

\section{Methodology}

\section{Study zone}

The study was conducted in North-East Benin precisely in the departments of Borgou and Alibori. The commune of Kalalé was the area of investigation because it sheltered the 4 th edition of the FAP, point of reference of this study. It was the meeting place for economic actors from the departments of Borgou and Alibori. This commune is located in northern Benin, and more precisely in the north-east of the Borgou department. She is limited to the north by the municipality of Ségbana (Department of Alibori), to the south by that of Nikki, to the east by the Federal Republic of Nigeria and to the west by the communes of Bembèrèkè and Gogounou. Its area is estimated at $3,586 \mathrm{~km} 2$ and represents respectively $13.87 \%$ and $3.18 \%$ of the area of the department and the national area. It is organized in six districts that are: Basso, Bouca, Dérassi, Dunkassa, Kalalé and Péonga. Kalalé has a Sudano-Sahelian climate characterized by two seasons in the year: a rainy season (from April to October) and a dry season (from November to March). The dominant economic activity practiced in the municipality of Kalalé is agriculture. More than $80 \%$ of the population with male dominance lives on agriculture and livestock. The main crops grown are maize, yams, cotton, cassava, sorghum, peanuts, beans and soybeans. Agri-food processing, cattle breeding and poultry farming are also highly developed.

\section{Methodological approach}

The study is carried out on the economic actors coming from the departments of Borgou and Alibori and which are invested a priori in the agriculture, the breeding, and the agro alimentary transformation. The collection method is essentially inspired by who studied the determinants of the adoption of agricultural technologies in North Benin [11,12]. An enumeration allowed for an exhaustive list of present showmen and to record 115 actors in total. However, due to limited time and financial resources only 50 fairgrounds were the subject of this study. The accidental sampling method was used to select fairground visitors. It consisted in investigating the showmen present on the spot. The information was collected through individual interviews based on a survey questionnaire (quantitative data) and an interview guide (qualitative data and about fairground visitors). The data collected relates to the characteristics, motivations and satisfaction of fairground visitors.

\section{Statistical analysis}

The analyzes were essentially performed using the Statistics Package for Social Sciences (SPSS) software. The tests performed with this software include descriptive analysis, reliability analysis, correlation testing, and speech analysis. The descriptive analysis was used to determine frequencies, averages, qualitative variables (sex, ethnicity, department ...) as well as the average of the quantitative data collected (turnover and note given to the organizers by the fairgrounds). The correlation test allowed the identification of items with a strong link before analyzing their reliability thanks to cronbach's alpha. At the end of the test and the reliability analysis, three out of five items were selected for each type of motivation (see Table 1). These items were selected based on the fact that the combination of items must give a cronbach alpha value approaching or exceeding the $70 \%$ threshold to be considered a reliable measurement scale [13]. Discourse analysis has also been useful in transcribing the perception of fairgrounds with regard to their satisfactions.

Table 1: Reliability of motivational items Results and discussion.

\begin{tabular}{|c|c|c|}
\hline Motivations & Items & Alpha of Cronbach \\
\hline \multirow{3}{*}{ Intrinsic } & $\begin{array}{l}\text { Improve your production } \\
\text { technique }\end{array}$ & \multirow{3}{*}{0,64} \\
\hline & $\begin{array}{l}\text { Improve your marketing } \\
\text { technique }\end{array}$ & \\
\hline & $\begin{array}{l}\text { To form friendly and business } \\
\text { relations }\end{array}$ & \\
\hline \multirow{3}{*}{ Extrinsic } & Costs of Affordable Participation & \multirow{3}{*}{0,60} \\
\hline & Make a good turnover & \\
\hline & $\begin{array}{l}\text { Make the honor of your } \\
\text { municipality }\end{array}$ & \\
\hline
\end{tabular}

\section{Results and Discussion}

\section{Characteristic features of the participants in the fair}

Table 2 presents the descriptive statistics of the variables used to characterize the showmen present at the Kalalé fair. His analysis reveals that the people surveyed come from two departments: Borgou and Alibori. Seven municipalities were present at this fair on behalf of the Borgou and four municipalities on behalf of the Alibori. This high number of municipalities representing the Borgou is justified by the fact that it houses the event on behalf of this edition. Among the exhibitors, the high representation of women ( $68 \%$ versus $32 \%$ for men) is noticeable. On the basis of the articles exhibited at the fairgrounds, a categorization allowed to obtain five sectors of activity. These include agriculture, agri-food, livestock, agricultural crafts, and animal health. As mentioned in Table 2, of these five sectors, the most dominant are agriculture and agri-food. From a cultural diversity point of view, there are five ethnic groups at the FAP Kalalé. This is according to the order of dominance of Baribas, Peulhs, Boo, Dendi, and Zerma. Of the 50 showmen in the study sample, $48 \%$ were first-time attendees, $20 \%$ second-year attendees, $6 \%$ third-year attendees, and $26 \%$ fourth-year attendees. Thus, $52 \%$ of these showmen are 
considered old and 48\% new. These results undoubtedly testify to the regularity of the participants in the different editions of the FAP. The same table includes the results obtained following a categorization of fairground performers according to whether they participate in their own names, on behalf of a group or on behalf of another parallel structure. The results of the statistical analysis reveal that more than half of the showmen are members of a group. This high rate of fairground group members in the sample reveals the effort made in their organization into a group. It also shows that they are the first beneficiaries of the project.

Table 2: Description of the variables collected

\begin{tabular}{|c|c|c|}
\hline Variables & Modalities & Relative Frequency (\%) \\
\hline \multirow{2}{*}{ Sex } & Man & 32 \\
\hline & Wife & 68 \\
\hline \multirow{5}{*}{ Ethnic group } & They are afraid & 42 \\
\hline & Peulh & 24 \\
\hline & Boo & 24 \\
\hline & Dendi & 4 \\
\hline & Zerma & 6 \\
\hline \multirow{5}{*}{ Sectors } & Food & 68 \\
\hline & Agriculture & 16 \\
\hline & Agricultural crafts & 6 \\
\hline & Breeding & 5 \\
\hline & Textile & 2 \\
\hline \multirow{4}{*}{$\begin{array}{c}\text { Number of } \\
\text { participation }\end{array}$} & first & 48 \\
\hline & Second & 20 \\
\hline & Third & 6 \\
\hline & Fourth & 26 \\
\hline \multirow{2}{*}{ Status } & Former & 52 \\
\hline & New & 48 \\
\hline \multirow{3}{*}{ Fair category } & Individual & 24 \\
\hline & Represented by a group & 70 \\
\hline & $\begin{array}{l}\text { Represented by other } \\
\text { structures }\end{array}$ & 6 \\
\hline
\end{tabular}

\section{Motivation of Fair Grounders}

\section{Measure of the types of motivation}

Table 3: Motivation Measure.

\begin{tabular}{|c|c|c|c|c|}
\hline $\begin{array}{c}\text { Type of } \\
\text { Motivation }\end{array}$ & Minimum & Maximum & $\begin{array}{c}\text { Absolute } \\
\text { Frequency }\end{array}$ & $\begin{array}{c}\text { Standard } \\
\text { Deviation }\end{array}$ \\
\hline Extrinsic & 9 & 25 & 18,24 & 3,946 \\
\hline Intrinsic & 16 & 25 & 23,90 & 2,243 \\
\hline
\end{tabular}

Table 3 presents the results obtained after measuring the types of motivations recorded in fairgrounds. The analysis of this table reveals that the dominant motivation at the level of the participants of the agro-pastoral fair is the intrinsic one. This means that the main reasons for fairground participation at the fair are not instrumental. Although it is also important for them to sell in order to cover the costs involved in this participation.

\section{Breakdown by type of motivation}

Motivation by municipality and sector of activity: The project (PASDeR) accompanying the OSP (Organization SocioProfessional) in the organization of agro-pastoral fairs gives priority to the four pilot areas members of the two departments (Gogounou, N'Dali, Banikoara, Kalalé). This is one of the reasons why the three previous editions took place in these communes. Table 4 presents the motivations of fairgrounds by sector of activity and by municipality. His analysis indicates that the intrinsic motivation of fairgrounds from Kandi (non-pilot area) is approximately the same as that of fairground visitors from Kalalé (pilot area). This means that the communes, whether they are chosen as the pilot area or not of the PASF, do not really have any effect on the intrinsic motivation of the fair grounders. Motivation averages were similarly compared between three business sectors. These are: agriculture, agri-food and livestock. From the result generated by this analysis, we observe that breeders from the intrinsic and extrinsic point of view have lower motivations than farmers and processors. This low motivation of fairground farmers is justified by the fact that this sector requires the mobilization of a large capital because of its requirements as regards the feeding and the maintenance of the animals.

Table 4: Comparison of motivations by municipalities and sectors of activity Satisfaction of fair grounders Satisfaction from the economic point of view.

\begin{tabular}{|c|c|c|c|}
\hline \multirow{2}{*}{ Variables } & \multirow{2}{*}{ modalities } & \multicolumn{2}{|c|}{ Motivations } \\
\cline { 3 - 4 } & & Intrinsic & Extrinsic \\
\hline \multirow{2}{*}{ Communes } & clean & 24,07 & 20,93 \\
\cline { 2 - 4 } & Kandi & 24,83 & 16,17 \\
\hline \multirow{3}{*}{ Sectors } & Agriculture & 24,38 & 19,63 \\
\cline { 2 - 4 } & Breeding & 19,33 & 14,67 \\
\cline { 2 - 4 } & Food & 24,18 & 18,74 \\
\hline
\end{tabular}

The first aim pursued in the organization of an agro-pastoral fair is to allow the participants to make good sales figures. The economic actor participating in the agro-pastoral fair hopes in the end to be satisfied with his income. Income is one of the motives for which he participates. It can be seen from Table 5 that the turnover achieved by fairgrounds is between 0 and 250,000 CFA francs and that $29181 \mathrm{fr}$ is the average of the turnover generated. However, participation in a fair of similar size, generates revenue but also causes expenses, especially for non-native fairgrounds. The realization of the turnover being one of the reasons for their participation, it is important to have an idea on the perception that these actors have of their receipts. The analysis in Table 5 also indicates that more than half (56\%) of the showmen surveyed estimate that their turnover exceeds their expenses. Of these, $48 \%$ are quite satisfied with their sale and $8 \%$ are very satisfied. On the other hand, $36 \%$ felt that their incomes are lower than their expenses. Among thesev, a fairground commented on the economic situation of the market. Mr. X said in this regard: "The market is cold, people just come to watch, and they leave. They 
say they do not have money in these times and if after the harvests they would buy a lot."

Table 5: Turnover and revenue perception of revenues and expenses. Source: Analysis Results, 2017

\begin{tabular}{|c|c|c|c|}
\hline Variables & Minimum & Maximum & Average \\
\hline Turnover & 0 & 250000 & 29181,00 \\
\hline Variables & Modalities & \multicolumn{2}{|c|}{ Fréquence (\%) } \\
\hline \multirow{5}{*}{$\begin{array}{l}\text { Perception of } \\
\text { income from } \\
\text { the fair }\end{array}$} & $\begin{array}{l}\text { Revenues well below } \\
\text { expenses }\end{array}$ & \multicolumn{2}{|c|}{18} \\
\hline & Revenue below expenses & \multicolumn{2}{|c|}{18} \\
\hline & $\begin{array}{l}\text { Revenue substantially } \\
\text { equal to expenses }\end{array}$ & \multicolumn{2}{|c|}{10} \\
\hline & Revenue above expenses & \multicolumn{2}{|c|}{46} \\
\hline & $\begin{array}{l}\text { Revenues well above } \\
\text { expenses }\end{array}$ & \multicolumn{2}{|c|}{8} \\
\hline
\end{tabular}

Satisfaction from the point of view business relationship and acquisition of experience: Apart from the economic aspect, as shown in Table $6,74 \%$ of the showmen surveyed have entered into partnership relations. Only $26 \%$ have not established a business relationship during this edition of the fair. In addition, the fair is a forum for exchanges and knowledge sharing. $98 \%$ of fair grounders surveyed have also acknowledged having acquired or shared experience at the end of this fair agropastoral. They admitted to having learned something new that allowed them to improve their production and marketing techniques. Mrs. Y a fairground expressed herself in these terms: "I am in my fourth FAP participation and have been trained in the processing of breadmaking flour products. I shared my knowledge more in this way. Many people have come to me to tell them how I get my breadmaking flour and other by-products. "

Table 6: Business Relationship and Experience Acquisition and Rating Awarded to the Fair Organization. Source: Analysis Results, 2017.

\begin{tabular}{|c|c|c|c|}
\hline Variables & Modalities & \multicolumn{2}{|c|}{ Frequency (\%) } \\
\hline \multirow{4}{*}{ Business relationship } & Any & \multicolumn{2}{|c|}{26} \\
\hline & With a person & \multicolumn{2}{|c|}{4} \\
\hline & $\begin{array}{l}\text { With two } \\
\text { people }\end{array}$ & \multicolumn{2}{|c|}{18} \\
\hline & $\begin{array}{l}\text { With three or } \\
\text { more people }\end{array}$ & \multicolumn{2}{|c|}{52} \\
\hline \multirow{2}{*}{ Experience acquisition } & Yes & \multicolumn{2}{|c|}{98} \\
\hline & Non & \multicolumn{2}{|c|}{2} \\
\hline Variable & Minimum & Maximum & Average \\
\hline $\begin{array}{l}\text { Rating attribution to the } \\
\text { organization (5) }\end{array}$ & 2 & 5 & 3,92 \\
\hline
\end{tabular}

Paying particular attention to the degree of satisfaction of fairgrounds, we note that more than half is $66 \%$ has a fairly good satisfaction of participation in this fair. $18 \%$ had a very good satisfaction and $16 \%$ had average satisfaction. This is confirmed by the average score of 3.92 out of 5 given to the organizers by the showmen and by the fact that the showmen interviewed unanimously wish a re-edition of the fair (Table 7).
Mrs. Z a fairground said in this regard: "I am very happy to have participated in this fair. If I had to give a note to the organizers I would give them even $21 / 20$ if it was possible. "

Table 7: Degree of satisfaction and reissue of the fair

\begin{tabular}{|c|c|c|}
\hline Variables & Modalities & Frequency (\%) \\
\hline \multirow{3}{*}{ Degree of satisfaction } & Poor & 0 \\
\cline { 2 - 3 } & Way & 16 \\
\cline { 2 - 3 } & Good enough & 66 \\
\cline { 2 - 3 } & Very good & 18 \\
\hline \multirow{2}{*}{ Reissue } & Yes & 100 \\
\cline { 2 - 3 } & Non & 0 \\
\hline
\end{tabular}

\section{Conclusion}

The present study was carried out in Kalalé commune and deals with the analysis of the determinants of the participation of economic actors in the agro-pastoral fair of Borgou-Alibori. It appears that the FAP of Borgou-Alibori brings together a large number of economic actors, primarily agricultural, from the municipalities that are members of the two departments. These actors, most of whom are affiliated to a socio-professional organization, are mainly women who invest in the agri-food and agricultural sectors.

The zoom made on the agro-pastoral fair in Kalalé made it possible to identify the types of motivation that, depending on their intensity, lead these actors to mobilize themselves for the event. The result obtained reveals that the intrinsic motivation of these actors takes precedence over extrinsic motivation. An average comparison between the types of motivations of the sectors of activity revealed that the breeders are less motivated than the actors of the other sectors. On the other hand, almost all the showmen surveyed express a satisfaction ranging from the " average " degree to the " high " degree, thus making a note of their appreciations of the event. While fairground reviews are good overall, there are some constraints that do not favor unanimity on the high degree of their satisfaction. Among these constraints is the inadequate period at which the fair took place.

\section{References}

1. RNDH (2015) Agriculture, Food Security, National Human Development Report, Cotonou, Benin, pp.144.

2. APRM (2014) Agricultural Sector Performance Report, Management 2013, Benin Pp.132.

3. Ben Hammouda H, Karingi S, Oulmane N, Jallab MS (2005) Can Access to Markets Help African Agriculture? Pp.59.

4. Lothor, Delmas P (2009) Market Access and Marketing of Agricultural Products Valorisation of Producer Initiatives, Cotonou, Benin pp.178.

5. Fedevaco (2015) A repertoire of actions to strengthen access to the market and the marketing of agricultural, agricultural products Preface, Lausanne pp.26.

6. Bouchitté, Darde S (2008) Agricultural Markets and Small Producers - Access Instruments and Risk Management, Cotonou, Benin pp. 6-7.

7. Rural H (2017) Platform for Support to Rural Development in West and Central Africa, Dakar, Senegal pp.57. 
8. Ettelbruck, Luxembourg (2018) presentation of the fair on 31/03/18.

9. PASDeR, (2017) Annual Progress Report 2016, Rural Development Sector Support Program (PASF, Phase 2), Cotonou, Benin pp.74.

10. PASDeR (2016) Capitalization Report, Capitalization of Phase 1 of the Rural Development Sector Support Program (PASDeR) in the departments of Borgou and Alibori (North Benin), Benin.

11. Miassi Y, Dossa F (2018) Socio-Economic Determinants of the Adoption of Agricultural Contracts: Case of Cashew Farmers in North-Eastern Benin, Int. J. Progress. Sci. Technol 6(2): 243-250.
12. Dossa F, Miassi Y (2018) Socio-Economic Factors Influencing the Adoption of Organic Cotton in North-East Benin: Case of Kandi Commune, Int. J. Progress. Sci. Technol 6(2): 577-584.

13. Daghfous N, Saadi M (2013) The implementation of the relational approach in Financial Institutions: The success factors, the brakes and the benefits sought, in Paper presented at the $81^{\text {st }}$ Congress of the Canadian Association- French for the advancement of science ACFAS pp. 11.
- Quality Editorial service

- Swift Peer Review

- Reprints availability

- E-prints Service

- Manuscript Podcast for convenient understanding

- Global attainment for your research

- Manuscript accessibility in different formats

( Pdf, E-pub, Full Text, Audio)

- Unceasing customer service

Track the below URL for one-step submission https://juniperpublishers.com/online-submission.php 